\title{
Effects of 8 Weeks of Resistance Training and IGF-1 Injection on Biochemical Markers of Cancer and Colorectal Structures in Rats
}

Babisan Askari (PhD candidate) Department of Sport Physiology, Faculty of Physical Education and Sport Sciences, Ferdowsi University of Mashhad, Mashhad, Iran

Nahid Bijeh (PhD)

Department of Sport Physiology, Faculty of Physical Education and Sport Sciences, Ferdowsi University of Mashhad, Mashhad, Iran

Amir Rashid Lamir (PhD) Department of Sport Physiology, Faculty of Physical Education and Sport Sciences, Ferdowsi University of Mashhad, Mashhad, Iran

Corresponding author: Dr Nahid Bijeh

Tel: 09155072745

Email: bijeh@ferdowsi.um.ac.ir

Address: Faculty of Physical

Education and Sport Sciences,

Ferdowsi University of Mashhad,

Mashhad, Iran

Received : 8 Oct 2017

Revised: 01 Nov 2017

Accepted: 09 Nov 2017
ABSTRACT

Background and Objectives: We studied effects of eight weeks of resistance training and IGF-1 injection on serum level of IGF-1, IGFBP-3 and IGF-1/IGFBP-3 ratio in Wistar rats.

Methods: We randomly divided 20 male Wistar rats into four groups of salineinjected control (C), resistance training+saline injection (RS), resistance training+IGF-1 injection (RI) and IGF-1 injection (II). Resistance training protocol consisted of climbing a ladder (three days/week with 5 reps/3 sets) while carrying a weight suspended from the tail for eight weeks. IGF-1 and saline $(1.5 \mu \mathrm{g} / \mathrm{kg} /$ day $)$ were injected before and after exercise sessions. Serum IGF-1, IGFBP-3 and IGF-1/IGFBP-3 ratio and morphology of colorectal tissue were evaluated.

Results: Serum IGF-1 level and IGF-1/IGFBP-3 ratio decreased in the RS group compared to the other groups $(\mathrm{P}<0.05)$. Rats in the RS group had higher IGFBP-3 level than those in the II and RI groups $(\mathrm{P}<0.05)$. IGF-1 injection had no effect on morphology of colorectal tissue.

Conclusion: The resistance training reduces IGF-1 and increases IGFBP-3 levels, which might represent a link between resistance training and lower risk of colorectal cancer.

Keywords: Exercise, Colorectal, Insulin-Like Growth Factor-1, Insulin-like Growth Factor Binding Protein-3. 


\section{INTRODUCTION}

Insulin-like growth factor 1 (IGF-1) and IGF binding protein 3 (IGFBP-3) have a key role in regulation of cell metabolism, growth, proliferation and apoptosis in multiple organs (1). Serum IGFBP-3 level is considered as the most important circulating IGF carrier protein, accounting for $90-95 \%$ of the circulating IGF1 (2). Growth hormone $(\mathrm{GH})$ increases hepatic production of both IGF-1 and IGFBP-3, which, at least in part, may account for the positive association between circulating levels of IGF-1 and IGFBP-3 (3). This suggests that circulatory IGF-1 and IGFBP-3 level may be an early important indicator of tumor growth in the body (4). IGF-1 prevents apoptosis via activation of the PI3K-Akt and JAK/STAT pathways (4), but IGFBP-3 has an opposite effect (5). Increased circulating IGF-1 levels, decreased IGFBP-3 levels and/or increased IGF-1/IGFBP-3 ratio might increase tumor growth, and have been reported to be associated with a higher risk of developing several types of cancer in both men and women (6). Therefore, downregulation of IGF1 and upregulation of IGFBP-3 may have protective effects against certain types of cancer, including colorectal, prostate, breast, and endometrial cancer (7).

Physical activity may help prevent cancer by inducing a reduction in circulating level of multiple hormones, particularly IGF-1 (4). While nutrition is an important determinant of circulating IGF-1 level (8), exercise is another potentially important regulator of IGF-1 (9). Exercise mobilises systemic IGF-1 from the liver and acute exercise mobilises circulating IGF-1 from active muscles (10). Some studies have reported that acute resistance and endurance exercise increase serum IGF-1 concentrations but do not affect serum IGFBP3 levels $(2,10,11)$. Although several studies have examined changes in circulating level of IGF-1 and IGFBP-3 in response to exercise training, the results of such studies have been inconsistent (12-19). Moreover, overexpression of IGF-1 and IGFBP-3 is thought to increase tumor size in colorectal cancer (9, 20). However, no study has yet investigated the effect of IGF-1 injection on IGF-1 and IGFBP-3 (as markers of colorectal cancer development), and colorectal tissues. Moreover, no study has yet investigated the effects of IGF-1 injection combined with resistance training on these factors. Thus, we aimed to examine the effects of eight weeks of resistance training with and without IGF-1 injection on the circulating level of IGF-1 and IGFBP-3 and morphology of colorectal tissue in rats.

\section{MATERIAL AND METHODS}

Animal care and all experimental procedures conformed to the animal care guidelines and were approved by the Ethics Committee of Ferdowsi University of Mashhad (protocol number: 21247). First, 28 young male Wistar rats aged 12 weeks and weighting $308 \pm 26.16 \mathrm{~g}$ were purchased from the Pasteur Institute of Iran. All subjects were kept in an environmentally controlled animal room (temperature: $22 \pm 2.0^{\circ} \mathrm{C}$ and humidity: $50-55 \%$ ) with a 12-hour light/dark cycle. All animals had access to standard rodent chow and water ad libitum. After a familiarization period of one week, the rats were randomly divided into four equal groups of salineinjected control (C), resistance training+saline injection (RS), resistance training+IGF-1 injection (RI) and IGF-1 injection (II). The rats were familiarized with climbing a ladder $\left(1 \times 0.18 \mathrm{~m}, 2-\mathrm{cm}\right.$ grid, $85^{\circ}$ incline $)$ with weights attached to their tails to simulate resistance exercise.

The RS and RI groups performed eight weeks of resistance training consisting of three sets of five repetitions, three times a week, with 1min rest intervals between the reps and 2-min intervals between the sets $(21,22)$. The initial weight attached to each animal's tail was $50 \%$ of its body weight and increased gradually throughout the eight weeks (22). Subjects in the $\mathrm{C}$ and II groups did not perform any exercise. Subjects in the II and RI groups received intramuscular IGF-I injection in the left calf and tibialis anterior muscles before and after the exercise sessions $(1.5 \mu \mathrm{g} / \mathrm{Kg}$ per day) (23). Rats in the $\mathrm{RS}$ and $\mathrm{C}$ groups received intramuscular saline injection at comparable times and doses.

The animals were anaesthetized $(75 \mathrm{mg} / \mathrm{Kg}$ ketamine and $25 \mathrm{mg} / \mathrm{Kg}$ xylazine) and then killed 72 hours after the last exercise session. Blood samples were obtained from the orbital sinus. The samples were centrifuged at 3000 RPM for $15 \mathrm{~min}$. The samples were stored at $20{ }^{\circ} \mathrm{C}$ for further analysis. Serum IGF-1 and IGFBP-3 levels were measured by ELISA kits (Hangzho Eastbiopharm, Elisa Kits, CAT.NO: 
CK-E30653- E91558) according to the manufacturer's protocol with lower limit of detection of $1.55 \mathrm{ng} / \mathrm{ml}$ and $0.93 \mathrm{ng} / \mathrm{ml}$, respectively. Colorectal tissues were collected and fixed in $10 \%$ formalin solution for $48 \mathrm{~h}$. The formalin solution was renewed after 24 hours. After alcohol-based fixation, tissue sections were rehydrated and subjected to paraffin embedding. Random sampling was performed from $5-\mu \mathrm{m}$ thick microtome sections at regular intervals (24). The sections were stained with haematoxylin and eosin and examined under a light microscope. Statistical analysis was performed using SPSS (version 20, IBM, Armonk, NY, USA). After assessing normality of the data (Shapiro-wilk test) and homogeneity of variance (Levene's test), data was analysed using one-way analysis of variance. The Tukey test was used in case of significant F-values. P-values $\leq 0.05$ were considered as statistically significant.

\section{RESULTS}

No significant difference was observed between the experimental groups in terms of body weight $(\mathrm{P}<0.05)$. Table 1 shows the serum level of IGF-1 and IGFBP-3 in all study groups. IGF-1 was significantly higher in the $\mathrm{RI}$ and II groups compared to that in $\mathrm{C}$ and $\mathrm{RS}$ groups $(\mathrm{P}<0.05)$.

The IGF-1 level was significantly lower in the RS group when compared with other groups $(\mathrm{P}<0.05)$. The IGF-1 level was significantly higher in the II group when compared with the other groups $(\mathrm{P}<0.05)$. Serum IGFBP-3 concentrations were significantly higher in the $\mathrm{C}$ and $\mathrm{RS}$ groups compared to those in RS and II groups $(\mathrm{P}<0.05)$. The IGFBP-3 level was higher in the RI group than that in II group $(\mathrm{P}>0.05)$.

Compared to control rats, the IGF-1/IGFBP-3 ratio was significantly higher in the II and RI groups.

In addition, the IGF-1/IGFBP-3 ratio was significantly lower in the RS group when compared with other groups. The IGF1/IGFBP-3 ratio was significantly higher in the II group compared to the IR group. Histological appearance of colorectal tissues was normal in all groups (Figure 1).

Table 1- Mean serum concentrations of IGF1, IGFBP-3 and IGF-1/IGFBP-3 ratio

\begin{tabular}{|c|c|c|c|c|}
\hline \multirow{3}{*}{ IGF1 (ng/ml) } & Group & Mean \pm SD & F-value & P-value \\
\hline & C & $340.98 \pm 27.88$ & \multirow[t]{2}{*}{112.54} & \multirow{2}{*}{ 0.001* } \\
\hline & II & $484.52 \pm 17.30^{\mathrm{a}}$ & & \\
\hline \multirow{6}{*}{$\begin{array}{c}\text { IGFBP-3 } \\
(\mathrm{ng} / \mathrm{ml})\end{array}$} & RI & $392.33 \pm 13.41^{\mathrm{a}, \mathrm{b}}$ & & \multirow{6}{*}{ 0.001* } \\
\hline & RS & $283.14 \pm 23.63^{a, c, d}$ & \multirow{5}{*}{21.40} & \\
\hline & $\mathrm{C}$ & $452.66 \pm 44.81$ & & \\
\hline & II & $358.69 \pm 36.63^{\mathrm{a}}$ & & \\
\hline & RI & $394.09 \pm 25.41^{\mathrm{a}}$ & & \\
\hline & RS & $497.98 \pm 31.48^{c, d}$ & & \\
\hline IGF - 1 & C & $0.76 \pm 0.10$ & \multirow[t]{4}{*}{92.73} & \multirow[t]{4}{*}{$0.001 *$} \\
\hline \multirow[t]{3}{*}{$\overline{\text { IGFBP }-3}$} & II & $1.36 \pm 0.12^{\mathrm{a}}$ & & \\
\hline & RI & $0.99 \pm 0.3^{\mathrm{a}, \mathrm{b}}$ & & \\
\hline & & $0.57 \pm 0.07^{\mathrm{a}, \mathrm{c}, \mathrm{d}}$ & & \\
\hline
\end{tabular}

* Significant difference at $\mathbf{P}<0.05$

a: significant difference with the control group

c: significant difference between II and RS

b: significant difference between II and RI

d: significant difference between RS and RI

Figure 1- Histopathological features of stained colorectal tissues (X40)
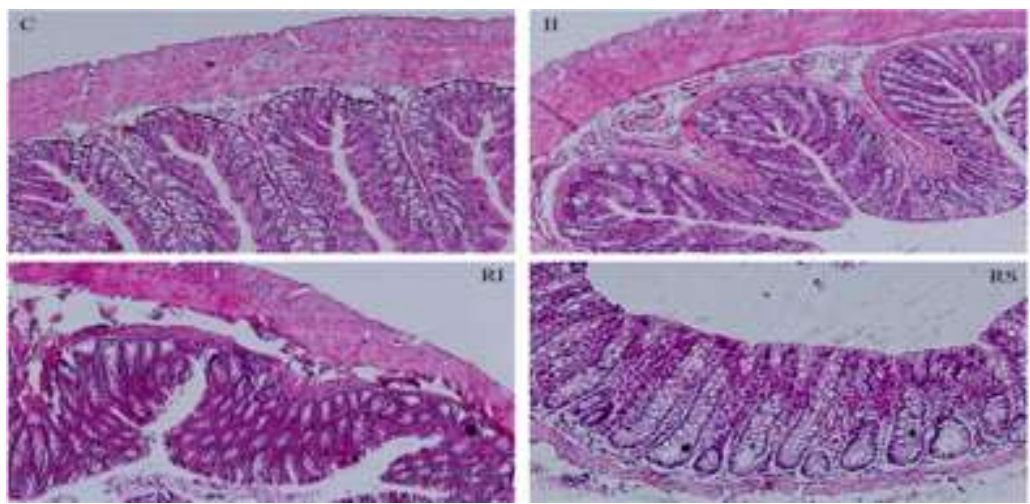


\section{DISCUSSION}

According to previous studies, IGF1 is associated with increased incidence of prostate, lung and colorectal cancer $(4,6)$, while high IGF1 level is associated with an increased risk of colorectal cancer (6). In addition, high IGF-1 and low IGFBP-3 levels increase the risk of colorectal cancer and villous adenomas (9). This study is the first to investigate the effect of exercise training and IGF1 injection on circulating level of IGF-1, IGFBP-3 and IGF-1/IGFBP-3 ratio. We assessed the effects of eight weeks of resistance exercise and IGF-1 injection on serum IGF-1 and IGFBP-3 concentrations in rats, and studied possible structural changes in colorectal tissues. We showed that the shortterm resistance training decreased the circulating IGF-1 concentrations and IGF1/IGFBP-3 ratio. The resistance training restored the increased IGF-1 and decreased IGFBP-3 levels induced by the IGF-1 injection. The 8-week IGF-1 injection had no effect on the structure of colorectal tissues. The resistance training did not affect body weight, which could be due to the fact that we did not use a high-intensity resistance training (25). Serum IGF-1 could be measured as a marker for development of several types of cancer $(6,19)$. We found that two months of exercise training decreased circulatory IGF-1, when compared with the control group. This is in line with the results of previous studies (7, 16, 17, 26). Evidence indicates that reduction of serum IGF-1 by lifestyle modification reduces the number of cancer cells, slows tumor progression and increases apoptosis in tumor cells $(3,7)$. We found that IGF-1 levels reduced in response to the training and IGF-1 injection. However, the exact mechanism of this phenomenon is not clear. Several biological mechanisms could explain exercise training-induced decrease in IGF-1, including increased post-receptor insulin signalling, increased glucose transporter protein and mRNA, decreased release and increased clearance of free fatty acids, and increased muscle glucose delivery $(17,27)$. In addition, decrease in pro-inflammatory cytokines (28) and increase in skeletal muscle IGF-1R density and activation may be other potential mechanisms for the exercise-induced reduction in systemic levels of IGF-1 (1). However, a mechanistic explanation is outside the scope of this study.
Some studies have reported that IGF-1 remained unchanged $(14,15)$ or increased $(18$, 19) after exercise training in women, older people and cancer patients. This could be because serum level of IGF-1 is affected by age, gender, body mass index, pre-training level, and health and nutritional status $(29,30)$. Prospective epidemiologic studies have shown that high levels of IGFBP-3, independent of IGF-1, were associated with a lower risk of cancer and colorectal adenoma (3). Since IGFBP-3 is considered as the main IGF-1 carrier, and IGF-1 has been thought to regulate IGFBP-3 levels (3), we also measured levels of circulatory IGFBP-3. IGFBP-3 protects IGF-1 from degradation and lowers the concentration of free IGF-1 (31). We found that the exercise training slightly increased concentration of the circulating IGFBP-3 and attenuated the decrease in IGFBP-3 of IR rats. The physiological effects of IGF-1 injection on decreased IGFBP-3 level in the II and IR groups and the mechanism involved in exercise training-induced increase in IGFBP-3 have not been clarified by this study. Since IGFI injection causes hypoglycemia, primarily by stimulating peripheral glucose uptake (32), and IGFBPs buffer the acute hypoglycemic effect of IGF-I (33), Nishida et al. suggested that the alterations in IGF-IGFBP-3 levels might be an adaptive response to prevent hypoglycemia following exercise training (7). According to previous studies, IGFBP-3 level might decrease (16), increase $(16,18,34)$, and remain unchanged (35-37) after exercise training. In study of Santa et al., IGFBP-3 increased in response to resistance training and decreased in response to aerobic training (16). In another study, IGFBP-3 levels decreased in untrained subjects until week four and returned to baseline by week 11, whereas no change was observed for well-trained individuals (34). The disparity in results of the mentioned studies could be due to the difference in exercise training models and characteristics of the study populations. Thus, the exact effect of exercise training on IGFBP-3 requires further examination.

Many studies suggest that the circulating IGF1/IGFBP-3 ratio may be a marker for bioavailability of circulatory and tissue IGF-1 (3). As mentioned earlier, GH increases hepatic production of both IGF-1 and IGFBP3. However, experimental data suggests that 
IGF-1 itself may also regulate hepatic IGFBP3 production (16). After eight weeks of training, we found that the mean value of IGF$1 /$ IGFBP-3 ratio decreased significantly in the RS group. The IR group had lower IGF1/IGFBP-3 ratio than compared to the II group. The increase in IGF-1/IGFBP-3 ratio in trained groups suggests that there may be more unbound IGF-1 available for hormone-receptor interactions (11).

Prolonged injection of GH and IGF-1 increases lean body mass improves muscle hypertrophy and reduces fat mass (38). Direct intramuscular injection of IGF-1 in combination with resistance training increased both body mass and strength more than each treatment alone $(38,39)$. In normal colorectal tissue, the long-term increase in IGF-1 bioavailability may increase the risk of colorectal cancer (40). In addition, the time required for malignant transformation is inversely associated with IGF bioactivity (31, 41). IGF-1 injection also promotes tumor progression and increases apoptosis in tumor cells, effects that are both reversed by dietary restriction in animal models (42). Likewise, injection of recombinant GH and IGF-1 has been found to promote tumor growth in vivo (43).

In our study, elevation of IGF-1 via injection caused no morphological or functional change on normal colorectal tissues. However, increasing the period of IGF-1 injection might

\section{REFERENCES}

1. Devin JL, Bolam KA, Jenkins DG, Skinner TL. The influence of exercise on the insulin-like growth factor axis in oncology: physiological basis, current, and future perspectives. Cancer Epidemiology and Prevention Biomarkers. 2015; 25(2): 239-49. doi: 10.1158/10559965.EPI-15-0406.

2. Rosa C, Vilaça-Alves J, Fernandes HM, Saavedra FJ, Pinto RS, dos Reis VM. Order effects of combined strength and endurance training on testosterone, cortisol, growth hormone, and IGF-1 binding protein 3 in concurrently trained men. The Journal of Strength \& Conditioning Research. 2015; 29(1): 74-9. doi: 10.1519/JSC.0000000000000610.

3. Sandhu MS, Dunger DB, Giovannucci EL. Insulin, insulin-like growth factor-I (IGF-I), IGF binding proteins, their biologic interactions, and colorectal cancer. Journal of the National Cancer Institute. 2002; 94(13): 972-80.

4. Ruiz-Casado A, Martín-Ruiz A, Pérez LM, Provencio M, Fiuza-Luces C, Lucia A. Exercise and the Hallmarks of Cancer. Trends in Cancer. 2017; 3(6): 423-41. induce such changes. The current study is the first to examine the short-term effects of IGF-1 injection on normal colorectal tissue. However, further studies should be performed to evaluate the long-term effects of IGF-1 injection on colorectal tissue.

\section{CONCLUSION}

Our preliminary results show that eight weeks of resistance training decreases circulating IGF-1 and IGF-1/IGFBP-3 ratio in male rats. Although, the 8-week IGF-1 injection caused no morphological and functional change in colorectal tissue, our results suggest that the IGF-1 increase and IGFBP-3 decrease caused by IGF-1 injection are attenuated by resistance training. Taken together, these novel findings suggest that short-term resistance training can reduce IGF1 and increase IGFBP-3 levels, which might be associated with lower risk of colorectal cancer.

\section{ACKNOWLEDGMENTS}

This article was derived from a $\mathrm{PhD}$ thesis in exercise physiology at the Ferdowsi University of Mashhad. The authors would like to thank the Ferdowsi University of Mashhad for supporting this research project.

\section{CONFLICT OF INTEREST}

The authors declare that there is no conflict of interest.

5. Brahmkhatri VP, Prasanna C, Atreya HS. Insulin-like growth factor system in cancer: novel targeted therapies. BioMed research international. 2015; 2015: 538019. doi: 10.1155/2015/538019.

6. Thomas RJ, Kenfield SA, Jimenez A. Exerciseinduced biochemical changes and their potential influence on cancer: a scientific review. Br J Sports Med. 2017; 51(8): 640-4.

7. Nishida Y, Matsubara T, Tobina T, Shindo M, Tokuyama K, Tanaka K, et al. Effect of low-intensity aerobic exercise on insulin-like growth factor-I and insulin-like growth factor-binding proteins in healthy men. International journal of endocrinology. 2010;2010(452820). doi: 10.1155/2010/452820.

8. Kaaks R, Lukanova A. Energy balance and cancer: the role of insulin and insulin-like growth factor-I. Proceedings of the Nutrition Society. 2001; 60(1): 91106.

9. Giovannucci E. Insulin, insulin-like growth factors and colon cancer: a review of the evidence. The Journal of nutrition. 2001; 131(11): 3109S-20S. 
10. Mannerkorpi K, Landin-Wilhelmsen K, Larsson A, Cider $\AA$, Arodell O, Bjersing JL. Acute effects of physical exercise on the serum insulin-like growth factor system in women with fibromyalgia. BMC musculoskeletal disorders. 2017; 18(1): 37. doi: 10.1186/s12891-0171402-y.

11. Sellami M, Dhahbi W, Hayes LD, Padulo J, Rhibi F, Djemail $\mathrm{H}$, et al. Combined sprint and resistance training abrogates age differences in somatotropic hormones. PloS one. 2017; 12(8): e0183184.

12. Wakai K, Suzuki K, Ito Y, Watanabe Y, Inaba Y, Tajima $\mathrm{K}$, et al. Time spent walking or exercising and blood levels of insulin-like growth factor-I (IGF-I) and IGF-binding protein-3 (IGFBP-3): a large-scale crosssectional study in the Japan Collaborative Cohort study. Asian Pac J Cancer Prev. 2009; 10(Suppl): 23-7.

13. Parekh N, Roberts $\mathrm{CB}$, Vadiveloo $\mathrm{M}$, Puvananayagam T, Albu JB, Lu-Yao GL. Lifestyle, anthropometric, and obesity-related physiologic determinants of insulin-like growth factor-1 in the Third National Health and Nutrition Examination Survey (1988-1994). Annals of epidemiology. 2010; 20(3):18293. doi: 10.1016/j.annepidem.

14. Fontana L, Klein S, Holloszy JO. Long-term lowprotein, low-calorie diet and endurance exercise modulate metabolic factors associated with cancer risk. The American journal of clinical nutrition. 2006; 84(6): 1456-62.

15. Borst SE, Vincent KR, Lowenthal DT, Braith RW. Effects of Resistance Training on Insulin-Like Growth Factor and its Binding Proteins in Men and Women Aged 60 to 85. Journal of the American Geriatrics Society. 2002; 50(5): 884-8.

16. Santa Mina D, Connor MK, Alibhai SM, Toren P, Guglietti C, Matthew AG, et al. Exercise effects on adipokines and the IGF axis in men with prostate cancer treated with androgen deprivation: a randomized study. Canadian Urological Association Journal. 2013;7(1112):E692-8. doi: 10.5489/cuaj.235.

17. Irwin ML, Varma K, Alvarez-Reeves M, Cadmus L, Wiley A, Chung GG, et al. Randomized controlled trial of aerobic exercise on insulin and insulin-like growth factors in breast cancer survivors: the Yale Exercise and Survivorship study. Cancer Epidemiology and Prevention Biomarkers. 2009; 18(1): 306-13. doi: 10.1158/10559965.

18. Lee DH, Kim JY, Lee MK, Lee C, Min J-H, Jeong $\mathrm{DH}$, et al. Effects of a 12-week home-based exercise program on the level of physical activity, insulin, and cytokines in colorectal cancer survivors: a pilot study. Supportive Care in Cancer. 2013; 21(9): 2537-45. doi: 10.1007/s00520-013-1822-7.

19.Koziris L, Hickson R, Chatterton R, Groseth R, Christie J, Goldflies D, et al. Serum levels of total and free IGF-I and IGFBP-3 are increased and maintained in long-term training. Journal of Applied Physiology. 1999; 86(4): 1436-42.

20. Shiratsuchi I, Akagi Y, Kawahara A, Kinugasa T, Romeo K, Yoshida T, et al. Expression of IGF-1 and $I G F-1 R$ and their relation to clinicopathological factors in colorectal cancer. Anticancer research. 2011; 31(7): 2541-5.
21. Lee S, Farrar RP. Resistance training induces muscle-specific changes in muscle mass and function in rat. Journal of Exercise physiology online. 2003; 6(2): 80-7.

22. Karbasi S, Zaeemi M, Mohri M, Rashidlamir A, Moosavi Z. Effects of testosterone enanthate and resistance training on myocardium in Wistar rats; clinical and anatomical pathology. Andrologia. 2017; e12908. doi: 10.1111/and.12908.

23. Adams GR, McCue SA. Localized injection of IGF-I results in skeletal muscle hypertrophy in rats. Journal of Applied Physiology. 1998;84(5):1716-22.

24.Rashidlamir A, Hosseini SRA, Hejazi K, Anberani SMM. The effect of eight weeks resistance and aerobic training on myostatin and follistatin expression in cardiac muscle of rats. Journal of cardiovascular and thoracic research. 2016;8(4):164-9. doi: 10.15171/jcvtr.2016.33.

25. Nucci RAB, Teodoro ACdS, Krause Neto W, Silva WdA, de Souza RR, Anaruma CA, et al. Effects of resistance training on liver structure and function of aged rats. The Aging Male. 2017; 11: 1-5. doi: 10.1080/13685538.2017.1350157.

26. Scheett TP, Nemet D, Stoppani J, Maresh CM, Newcomb R, Cooper DM. The effect of endurance-type exercise training on growth mediators and inflammatory cytokines in pre-pubertal and early pubertal males. Pediatric research. 2002; 52(4): 491-7.

27. Meneses-Echávez JF, Jiménez EG, Río-Valle JS, Correa-Bautista JE, Izquierdo $\mathrm{M}$, Ramírez-Vélez R. The insulin-like growth factor system is modulated by exercise in breast cancer survivors: a systematic review and meta-analysis. BMC cancer. 2016; 16(1): 682.

28.Eliakim A, Nemet D. Exercise training, physical fitness and the growth hormone-insulin-like growth factor-1 axis and cytokine balance. Med Sport Sci. 2010; 55: 128-40. doi: 10.1159/000321977.

29. Rosario PW. Normal values of serum IGF-1 in adults: results from a Brazilian population. Arq Bras Endocrinol Metabol. 2010; 54(5):477-81.

30. Veldhuis JD, Roelfsema F, Keenan DM, Pincus S. Gender, age, body mass index, and IGF-I individually and jointly determine distinct $G H$ dynamics: analyses in one hundred healthy adults. The Journal of Clinical Endocrinology \& Metabolism. 2011;96(1):115-21. doi: 10.1210/jc.2010-1669.

31. Shanmugalingam T, Bosco C, Ridley AJ, Van Hemelrijck M. Is there a role for IGF-1 in the development of second primary cancers? Cancer medicine. 2016;5(11):3353-67. doi: 10.1002/cam4.871.

32. Jacob R, Barrett E, Plewe G, Fagin KD, Sherwin RS. Acute effects of insulin-like growth factor I on glucose and amino acid metabolism in the awake fasted rat. Comparison with insulin. Journal of Clinical Investigation. 1989; 83(5): 1717-23.

33. Jones JI, Clemmons DR. Insulin-like growth factors and their binding proteins: biological actions. Endocrine reviews. 1995; 16(1): 3-34.

34. Rosendal L, Langberg H, Flyvbjerg A, Frystyk J, Ørskov H, Kjær M. Physical capacity influences the response of insulin-like growth factor and its binding proteins to training. Journal of Applied Physiology. 2002; 93(5): 1669-75. 
35. Schmitz KH, Ahmed RL, Hannan PJ, Yee D. Safety and efficacy of weight training in recent breast cancer survivors to alter body composition, insulin, and insulinlike growth factor axis proteins. Cancer Epidemiology and Prevention Biomarkers. 2005; 14(7): 1672-80.

36. Eliakim A, Brasel JA, Mohan S, Wong WLT, Cooper DM. Increased physical activity and the growth hormone-IGF-I axis in adolescent males. American Journal of Physiology-Regulatory, Integrative and Comparative Physiology. 1998; 275(1): R308-R14.

37. Maddalozzo G, Snow C. High intensity resistance training: effects on bone in older men and women. Calcified tissue international. 2000; 66(6): 399-404.

38. Herndon DN, Ramzy PI, DebRoy MA, Zheng M, Ferrando AA, Chinkes DL, et al. Muscle protein catabolism after severe burn: effects of IGF-1/IGFBP-3 treatment. Annals of surgery. 1999; 229(5): 713-20.

39. Holt R, Sönksen P. Growth hormone, IGF-I and insulin and their abuse in sport. British journal of pharmacology. 2008; 154(3): 542-56. doi: 10.1038/bjp.2008.99.
40. Gunter MJ, Leitzmann MF. Obesity and colorectal cancer: epidemiology, mechanisms and candidate genes. The Journal of nutritional biochemistry. 2006;17(3):14556.

41. Nomura AM, Stemmermann GN, Lee J, Pollak MN. Serum insulin-like growth factor I and subsequent risk of colorectal cancer among Japanese-American men. American journal of epidemiology. 2003; 158(5): 42431.

42. Kari F, Dunn S, French J, Barrett J. Roles for insulinlike growth factor-1 in mediating the anti-carcinogenic effects of caloric restriction. The journal of nutrition, health \& aging. 1999; 3(2): 92-101.

43.Butler AA, Blakesley VA, Tsokos M, Pouliki V, Wood TL, LeRoith D. Stimulation of tumor growth by recombinant human insulin-like growth factor-I (IGF-I) is dependent on the dose and the level of IGF-I receptor expression. Cancer research. 1998; 58(14): 3021-7. 